\title{
Perspectives of Christmas rose (Helleborus niger L.) genetic improvement
}

\author{
Andrej ŠUŠEK \\ University of Maribor, Faculty of Agriculture and Life Sciences, Pivola 10, 2311 Hoče, Slovenia
}

\begin{abstract}
The Christmas rose is becoming a very important ornamental plant on the market. It is relatively new to intensive production technologies. The number of genetically-improved varieties on the market is limited, and many of the old cultivars are no longer available because of slow and economically unfeasible vegetative propagation. In the future, its genetic improvement will probably become inevitable. New cultivars will have to satisfy the specific requirements of the market and producers as well as strict environmental policy. In order to obtain new cultivars it will be necessary to evaluate the exsisting germplasm and apply an adequate genetic breeding approach. There are seven main possibilities of creating new varieties: the use of natural variation associated with seed germination, population approach based on recurrent selection, individual selection based on specific genetic combinations, the creation of inbred lines and the formation of hybrids, interspecific hybridisation, mutagenesis and genetic engineering. Molecular markers can be very helpful during the breeding process. They can be used in order to study genetic relationships amongst populations, ecotypes, varieties, and hybrids.
\end{abstract}

Kew words: Christmas rose, Helleborus niger, cultivars, breeding perspectives

\section{INTRODUCTION}

The genus Helleborus L. (family Ranunculaceae) is comprised of about 16 species of herbaceous perennials, which are dispersed throughout Central and Southern Europe (including the Mediterranean) and as far as to the Caucasus and China (Mathew 1989). The Christmas rose (Helleborus niger L.) grows wild in the southern, and occasionally the northern Dolomites and Apennines, in the mountain forests of the southern Alps and the north-western Balkans. Under natural conditions, the Christmas rose is a rhizomatous, evergreen perennial, $15-30 \mathrm{~cm}$ high, admired for its very early flowers and attractive leaves. In its native habitats, the Christmas rose flowers from November to April (Hegi 1975). The flowering period depends on several factors such as genotype, age, presence of pests and diseases, soil fertility, geographical position and specific climatic conditions.

The Christmas rose is one of the earliest flowering plant species from the genus Helleborus. Its ability to bloom during the 'darkest' months of the year, when everything else is frozen, makes it highly valuable. According to its natural flowering time (from November to April), it does not need high temperatures to start flowering and this is very important for producers in moderate continental climates. Greenhouses within moderate continental climatic conditions, due to their specific structures, are large energy consumers and therefore very expensive for producers. The Christmas rose doesn't need high temperatures and for this reason it can be considered as a cost efficient and friendly to the environment.

The Christmas rose is becoming more and more popular on the market as an ornamental plant. According to the FloraHolland auction, as the International market leader in floriculture sales, Helleborus is traded as an outdoor plant. In 2010, the total sales of Helleborus was worth 6 million euros and was placed in 9th place amongst the top 25 outdoor commercial ornamental species. In 2014 they sold Helleborus plants worth 12 million euros and were in 8 th place (FloraHolland 2010, 2014). The Christmas rose can also be grown as cut-flowers or pot plants, and can be forced to flower under greenhouse conditions around Christmas or New Year (Lemper 1984, 1985). 


\section{CULTIVATION OF THE CHRISTMAS ROSE IN THE FUTURE}

In the future, the Christmas rose will probably become a much more important ornamental species than it is now. However, it is difficult to predict what will happen regarding its cultivation. Its popularity will depend on several factors, such as the availability of other competitive species on the market, economics of cultivation; especially the expenses associated with reproduction, general prosperity of the economy, marketing approaches and the availability of highly attractive cultivars. Multiplication of such cultivars will probably remain as one of the key factors. The multiplication coefficient based on rhizome cuttings is relatively low, and it takes a long time for newly developed cultivars to be multiplied to such a level that they can be sold on the market. Market preferences could change during this necessary period. Efficient multiplication will therefore be essential for successful cultivation and marketing.

The Christmas roses are often grown from seedlings or rhizome cuttings cultivated within disinfected soil or inert substrata, basically to lower the risk of contamination by pathogenic agents and to ensure controlled conditions in order to obtain a homogenous material. If it takes place under sterile conditions, it eliminates or drastically reduces the populations of most organisms that are normally present within the soil, including useful ones, such as plant growth promoting rhizobacteria (PGPR) and mycorrhizal fungi. Soil microorganisms, especially in the rhizosphere, are involved in most, if not all, plant-soil exchanges. It is likely that complex associations organisms play a major role in the stability of a natural ecosystem (Atlas and Bartha 1998). Soil microorganisms are of ecological importance, determining plant biodiversity, ecosystem variability, and productivity (Vessey 2003). Šušek et al. (2010) reported that inoculation with a single micro-organism species can have positive effects on the growth of Helleborus plants, especially on root growth. The effects on plant growth generally depend on the type of micro-organism and the microbial mixture introduced into the substrate (Dunabeitia et al. 2004). In the case of $H$. niger, it seemed that these micro-organisms used separately were the more efficient. Agrobacterium radiobacter was found to be stimulating the growth and the survival-rate of plants, and could be considered as an effective plant growth-promoting agent for those Christmas rose plants propagated by micropropagation or by rhizome cuttings (in vivo). However A. radiobacter and endomycorrhizal fungi mixtures have negative effects on the rate of plant survival and plant growth (Šušek et al. 2010). Therefore, an understanding of the complex relationship between micro-organisms and plants is a prerequisite for sustainable development.

The commercial production of the Christmas rose based on propagation from seed is probably the more efficient and the cheapest method of reproduction. However, it has been found to be unsuitable for registered varieties, since the seedlings are always phenotypically variable and unreliably display varietal characteristic such as flower colour, flower size, time of flowering or crucial leaf characteristics. In vivo vegetative propagation (via rhizome cuttings) has; for many years; played an important role during the commercial cultivation of the Christmas rose. Apart from commercial cultivation, it is also widely used in genetic breeding: for the multiplication of parental lines in order to ensure seed production. The classical method of in vivo vegetative propagation (cloning) is often too slow, too sophisticated and/or too expensive.

In the future, micropropagation will probably become a much more important technique employed during large scale production. It enables relatively fast multiplication, and the resulting plant materials are disease free. Since the discovery that plants can be more rapidly cloned in vitro than in vivo, knowledge concerning in vitro vegetative propagation has grown rapidly. However, in vitro cultivation of Helleborus is still considered to be difficult (Seyring 2002, Dhooghe and Van Labeke 2007). The main problems are the high deegre of pathogenic contamination when rhizome buds are used for initiating an aseptic culture, a high variation of offspring individuals if seedlings were used as initial explants, and a low multiplication rate of culture from meristem tips (Seyring 2002). Dhooghe and Van Labeke (2007) reported that they had successfully propagated $H$. niger by means of in vitro cloning and they had obtained a 3.8 multiplication rate. This protocol has to be futher optimized in order to be used as an efficient multiplication system.

\section{CHRISTMAS ROSE BREEDING}

\section{Christmas rose cultivars in the future}

In the future, Christmas rose cultivars will have to satisfy the demands of the existing markets that are highly selective, and producers will have to reduce the pollution within the environment (i.e., the use of pesticides will have to be drastically reduced). At the same time, energy for heating greenhouses will probably become very expensive.

Cultivars will have to be highly resistant to all crucial pests and diseases, well adapted to a variety of environments (changes of humidity and temperature), whilst at the same time retaining all attractive characteristics.

The cultivars used as poted plants will have to be compact, with shorter leaf petioles, smaller blades and shorter stems, and with flowers just above the leaf blades. For cut-flower cultivation, cultivars should be characterized by very long stems, several inflorescences and large flowers. The cultivars used as garden perennials should be adapted to a higher level of insolation, and the plants should be strong and vigorous, with many leaves and greater inflorescences. The flowering should last as long as possible.

Cultivars that can be classified strictly within these specific groups have yet to be created. The existing cultivars generally include characteristics from all three groups, and they can be grown as poted-plants, for cut flower growth production and as garden perennials. In order to obtain cultivars with the specific characteristics of the above mentioned groups it will be necessary to evaluate the existing germplasms and apply an adequate genetic breeding technique. Some of the traits, especially quantitatative with lower heritability, could be reasonably modified by agronomic practices such as exposure to light or shade, increased fertilization with nitrogen, keeping soil moisture at high or low levels, increasing temperature in 
greenhouses and the use of gibberellins.

\section{Available genetic resources for breeding}

The Christmas rose is distributed all over central Europe including northern Italy, the eastern parts of France, Switzerland, southern Germany, Austria, western Hungary, Croatia, Bosnia and Hercegovina and Slovenia. Large germplasm collections do not exist. In several countries (e.g., United Kingdom, Netherland, Germany, Belgium, USA, Japan, Australia, New Zealand) there are small collections that are used as genetic sources for direct selection in order to obtain materials suitable for commercial purposes or for genetic breeding.

Slovenia is one of the centres of diversity regarding the Christmas rose. Its genetic diversity is considered to be relatively high, which has been demonstrated by morphological and partly by molecular analyses (Šušek 2012). In order to get more information about the existing variation in Slovenia and other countries, it will be necessary to establish systematic national and international germplasm collections, and to describe accessions according to an appropriate descriptor list. Characterisation of genetic materials has to involve highly inheritable morphological traits which are important for the selection and/or are easy for any determination. Šušek (2007) and Šušek (2008) described 72 morphological traits that appear to be at least partly genetically controlled and could be used as descriptors of Christmas rose genotypes. The most important are listed in Table 1.
During current genetic breeding, the most urgently required resources are those for the following traits: growth vigour, dwarfness, long stems (tall plants), inflorescences with numerous flowers, large flowers, attractive floral colours, variegated floral colours, double flowers, slow and long-lasting flowering of individual flowers, continuous flowering over long periods, early flowering (in November), late flowering (from April to June), adaptability to extreme environments (dry, wet, shaded, exposed to full solar radiation), adaptability to greenhouse conditions, room conditions (when used as a potted plant), suitability for long-distance transport, tolerance of storage for long periods, resistance to all crucial diseases (black spot; false mildew; black root rhizome, stem, roots and crowns; crown rot; fusarium wilt; Bremia; Sclerotinia). At present, resistance to pests and diseases is not a priority because most cultivation is under controlled conditions where pesticides are regularly used. However, in order to reduce pollution of the environment, genetic resistance will probably become much more important and will also reduce production costs.

\section{Breeding approaches}

The Christmas rose is a relatively new cultivated species, and there are several traits that must be improved. Probably the main selection criteria in genetic improvement are the number of inflorescences per plant, the floral diameter and the peduncle length. The modern market requires large flowers, on long and strong peduncles. However, to make cultivation more efficient, it would also be necessary to increase the number of

Table 1: The most important taxonomic and morphological traits that can be used as descriptors of Helleborus niger genotypes (based on Šušek 2008 and Šušek et al. 2007)

\begin{tabular}{|l|l|}
\hline Trait & Variation range \\
\hline General characteristic & poor; intermediate; high; very high; other \\
\hline Growth vigor: & erect; semi-erect; semi-prostrate; prostrate (spreading); other \\
\hline Growth habit: & $<5 ; 5-10 ; 11-15 ; 16-20 ;>20$ \\
\hline Leaves & $\begin{array}{l}\text { vertical; semi-vertical; semi-horizontal; horizontal; horizontal with } \\
\text { drooping tip; horizontal with tip pointing upwards; other }\end{array}$ \\
\hline Number of leaves/plant: & $\begin{array}{l}\text { non-glossy (non-shining); glossy (shining); only young leaves glossy; } \\
\text { only mature leaves glossy; other }\end{array}$ \\
\hline Predominant lamina orientation: & $\begin{array}{l}\text { yellow; pale green; green; dark green; light purple; dark purple, } \\
\text { chimeras, variegations; other }\end{array}$ \\
\hline Lamina waxiness: & $<5 ; 5-10 ;>10$ \\
\hline Lamina colour: & elliptic; ovate; obovate; oblong-cuneate; oblanceolate; lanceolate \\
\hline Average number of leaflets: & acute; obtuse; other \\
\hline Shape of terminal leaflet: & attenuate; acute; cuneate; oblique; other \\
\hline Terminal leaflet tip: & entire; crenate; sinuate; dentate; denticulate; serrate; serrulate; other \\
\hline Terminal leaflet base: & \\
\hline Terminal leaflet margin: &
\end{tabular}


Table 1: (cont.)

\begin{tabular}{|c|c|}
\hline Trait & Variation range \\
\hline \multicolumn{2}{|l|}{ Leaves } \\
\hline Distribution of teeth of terminal leaflet: & no teeth; upper $1 / 3$; upper $2 / 3$; on whole margin; other \\
\hline \multicolumn{2}{|l|}{ Maximal width of terminal leaflet $(\mathrm{cm})$} \\
\hline \multicolumn{2}{|l|}{ Terminal leaflet length $(\mathrm{cm})$} \\
\hline \multicolumn{2}{|l|}{ Terminal leaflet width: length ratio } \\
\hline \multicolumn{2}{|l|}{ Pigmentation of main leaflet veins (colour chart) } \\
\hline \multicolumn{2}{|l|}{ Terminal leaflet stalk length $(\mathrm{cm})$} \\
\hline \multicolumn{2}{|l|}{ Petiole } \\
\hline \multicolumn{2}{|l|}{ Petiole junction colour (colour chart) } \\
\hline Petiole basic colour (colour chart): & colour of basal $1 / 3^{\text {rd }}$; colour of middle $1 / 3^{\text {rd }}$; colour of top $1 / 3^{\text {rd }}$ \\
\hline \multicolumn{2}{|l|}{ Petiole length $(\mathrm{cm})$} \\
\hline \multicolumn{2}{|l|}{ Peduncle $^{1}$} \\
\hline Penducle orientation: & erect; semi-erect; curved \\
\hline \multicolumn{2}{|l|}{ Peduncle length ${ }^{2}$} \\
\hline Number of bracts: & $0-1 ; 2-3 ; 4-5 ;>5$ \\
\hline Shape of bracts: & entire; divided \\
\hline Peduncle orientation: & erect; non-erect; curved; other \\
\hline Peduncle basic colour (colour chart): & colour of top $1 / 3$ rd; colour of middle $1 / 3 \mathrm{rd}$; colour of basal $1 / 3$ rd \\
\hline \multicolumn{2}{|l|}{ Inflorescence } \\
\hline Number of inflorescences per plant: & $<5 ; 6-10 ; 11-20 ; 21-30 ; 31-40 ; 41-50 ;>50$ \\
\hline Average number of flowers per inflorescence: & solitary flower; $2 ; 3 ; 4 ;>4$ \\
\hline \multicolumn{2}{|l|}{ Flower } \\
\hline Odour intensity: & absent; very weak; weak; moderate, strong \\
\hline Odour type: & pleasant; not pleasant; other \\
\hline Flower shape during anthesis: & flat; flattish; bell-shaped; narrow bell-shaped; other \\
\hline Position of floral axis: & erect; semi-erect, horizontal; drooping \\
\hline Flower diameter $(\mathrm{cm})$ : & $<4 ; 4-6 ; 6-8 ; 8-10 ; 10-12 ;>12$ \\
\hline Number of sepals: & $<5 ; 5 ; 6 ;>6$ \\
\hline Sepal shape: & elliptic; lanceolate; oblanceolate; oblong; obovate; ovate; oval; rhomboid \\
\hline Sepal margins: & entire; crenate; sinuate; dentate; denticulate; serrate; serrulate; \\
\hline \multicolumn{2}{|l|}{ Colour of sepals (adaxial side) (colour chart) } \\
\hline \multicolumn{2}{|l|}{ Colour of sepals (abaxial side) (colour chart) } \\
\hline \multicolumn{2}{|l|}{ Colour of sepal margins (colour chart) } \\
\hline Position of sepals: & separated; slightly fused at the base; overlapping; other \\
\hline
\end{tabular}


Table 1: (cont.)

\begin{tabular}{|c|c|}
\hline Trait & Variation range \\
\hline \multicolumn{2}{|l|}{ Flower } \\
\hline Number of stamens: & $1-30 ; 31-60 ; 61-90 ; 91-120 ;>120$ \\
\hline Position of anthers: & forming a circle around female portion; irregularly distributed; other \\
\hline Anther colour (during anthesis): & $\begin{array}{l}\text { light yellow (normal); dark yellow; pink; red; purple; blue or blue- } \\
\text { purple; other }\end{array}$ \\
\hline Number of carpels: & $<3 ; 3-6 ; 7-10 ;>10$ \\
\hline Colour of carpels at the beginning of anthesis : & $\begin{array}{l}\text { light yellow (indicating sterility); pale green (indicating poor vigour); } \\
\text { green; purple or purple-red; not uniform; variegated; other }\end{array}$ \\
\hline Style length: & $\begin{array}{l}\text { short }(<1 / 10 \text { of the pistil height }) \text {; intermediate }(1 / 10-1 / 5 \text { of the pistil } \\
\text { height }) ; \text { elongated }(>1 / 5 \text { of the pistil height })\end{array}$ \\
\hline Stigma pigmentation: & $\begin{array}{l}\text { light red; red or purple-red; blue or blue-purple; stigmas on the same } \\
\text { flower differ in colour; other }\end{array}$ \\
\hline Petal shape: & flat; flat with curved margin; tubular; funnel; other \\
\hline Number of petals: & $1-10 ; 11-15 ; 16-20 ;>20$ \\
\hline Petal colour: & yellow; yellow-green; green; green-purple; purple; variegated; other \\
\hline \multicolumn{2}{|l|}{ Fruit } \\
\hline Fruit formation: & absent; present; rarely present \\
\hline Mature fruit colour: & $\begin{array}{l}\text { yellowish green; green; dark green; green with red patches; red; purple; } \\
\text { other }\end{array}$ \\
\hline \multicolumn{2}{|l|}{ Number of fruits/plant } \\
\hline Number of seeds/fruit: & $<5 ; 5-10 ; 11-20 ;>20$ \\
\hline \multicolumn{2}{|l|}{ Seed } \\
\hline Seed colour: & $\begin{array}{l}\text { light (almost white); light brown; darker brown; darker red or purple; } \\
\text { black; colour variations within seeds from the same fruit head; other }\end{array}$ \\
\hline Dry seed shape: & elongated; elliptic; oval; conical; irregular; other \\
\hline
\end{tabular}

${ }^{1}$ mature peduncle (during flowering)

${ }^{2}$ the distance from soil surface to the base of the flower

inflorescences per plant. The number of inflorescences per plant is also directly associated with the plant's age. According to our observations, older plants that are characterised by larger rhizomes, a higher number of buds, more leaves and more efficient root systems generally have more inflorescences and more flowers per inflorescence (Šušek et al. 2005). At present, the most desired genotypes are those with 10 or more inflorescences, or with 2 large flowers per inflorescence. Such genotypes should be genetically recombined and in the resulting offspring populations the breeder should select the individuals with the highest number of flowers for a new series of crossings.

There are seven main possibilities when creating new varieties: (1) the use of natural variation associated with seed germination, (2) a population approach based on recurrent selection; (3) individual selection based on specific genetic combinations; (4) self-pollination aimed at creating of inbred lines and the formation of hybrids, (5) interspecific hybridisation, (6) mutagenesis and (7) genetic engineering.

The first approach is cheap and very useful. The natural variation of the Christmas rose has not yet been fully exploited. Seeds of morphologically interesting individuals growing in natural populations or germplasm collections are collected and germinated. Plants are evaluated and the desired ones are multiplied as potential new cultivars. Because of its predominant heterozygosity one can expect high genetic variation. This approach could be considered useful for at least two more decades.

The second approach is probably the most reasonable at this stage. It is the cheapest, and the breeder can easily form polycross plots using different genotypes, each carrying at least one useful trait, and using insects for genetic recombination. The resulting populations have to be evaluated, and the best genotypes can be multiplied as potential new cultivars; whilst 
at the same time being used as parental materials during the next breeding cycle. This process will enable the accumulation of desired alleles. Because of the specific situation, it would be reasonable to divide such a programme into four subprogrammes: (a) aimed at extremely tall genotypes, (b) aimed at an increased number of inflorescences per plant, (c) aimed at large flowers and (d) a sub-programme which will include interspecific hybridisation. We need to create populations of extremes (some of the extreme genotypes will probably be immediately used as new varieties on the market) and then to recombine them, to create genotypes that will combine several desired traits together. Each cycle of the recurrent selection would comprise three parts: (1) formation of a (new) population (by intercrossing of the superior plants), (2) analysis of individuals within the resulting population and (3) selection of the best individuals for new genetic recombinations; in order to form the population of the next cycle. In each new population, the frequencies of desired alleles (e.g. alleles associated with plant vigour, formation of a higher number of leaves and inflorescences per plant, etc.) will increase, whilst at the same time the genetic variation should remain high. This approach represents a continuous process, where candidate plants for potential new varieties could be selected in each cycle.

Superior genotypes can also be used for individual crosses in order to form genetically variable progenies that will be subjected to individual selection. This (third) approach will be much more effective when highly improved genotypes are already available for further genetic recombinations. Individual crosses will be used mainly for a small number of highly inherited traits.

Self-pollination can be considered as relatively simple because plants appear to be at least partly self-compatible. Once the inbred lines are available, the breeder has to determine the combining abilities of individual lines, and form hybrids that can be used as new potential cultivars and/or within further breeding programmes. This approach enables commercial production based on seed multiplication. Seed derived at from crosses of two inbred lines is geneticallyuniform and this means that it is possible to produce, over a relatively short period of time, genetically and phenotypically highly uniform plants for the market. This approach is being more and more frequently used in large private companies.

In terms of the specific reproductive characteristics of the species (protogyny, predominant insect pollination, abundance of pollen, self-compatibility, relatively high number of seeds obtained from one pollinated flower and one plant, simple techniques of artificial self- and crosspollination, a relatively long period from germination to flowering (approximately 3 years) and simple vegetative propagation), the best solution would be to use recurrent selection in order to improve population materials, and then to start with self-pollination combined with pedigree selection and testing of combining abilities and finally to create hybrids. Since the number of seeds obtained from one pollinated flower can exceed 50, it is reasonable to perform self-pollinations and/or crosses manually. In the future, the production of inbreeds and their hybrids will probably play an important role.

Interspecific hybridisation will also probably become more important in the near future. The investigations of Meiners and Winkelmann (2012) indicate that the success of such crosses depends strongly on the genetic distances amongst the involved species. Crossing barriers in Helleborus were localised as predominantly post-zygotic. In many cases, embryo rescue tehniques could be the solution. The sterility within the resulting progenies is not expected to be a serious problem due to vegetative propagation. So far, only four interspecific hybrids within the genus Helleborus have been listed to date: Helleborus $\times$ nigercors $(=H$. niger $\times H$. argutifolius $)$, Helleborus $\times$ ballardiae $(=H$. lividus $\times H$. niger $)$, Helleborus $\times$ sternii $(=$ $H$. lividus $\times H$. argutifolius $)$ and Helleborus $\times$ ericsmithii $(=H$. $\times$ sternii $\times H$. niger) (Mathew 1989). The data of some authors (e.g., Burrell and Tyler 2006) indicate that some combinations were very successful (Helleborus 'Ivory Prince', Helleborus 'Pink Ice', Helleborus 'Briar Rose', Helleborus 'Snow White', Heleborus multifidus $\times$ Helleborus $\times$ hybridus).

Mutagenesis is considered less useful. The chances of getting a completely new and useful trait are generally very low. This approach can be used mainly when a certain desired trait does not exist within the species and other related species that can then be used as potential parents for interspecific recombination. Examples of such traits could be blue and red sepals, large petals, tolerance for solar radiation, extreme shade and drought, continuous flowering throughout the year and male sterility that will facilitate hybridization.

Genetic engineering is one of the very powerful options for creating new varieties. It has not as yet been fully exploited. Regarding the Christmas rose the biggest chances are probably in the formations of new types of colours. Good examples are the roses (Nishihara and Nakatsuka 2011), tobaco (Nakatsuka et al. 2006), petunia (Jorgensen et al. 2002), etc.

For planning genetic recombination and selection, it would be very useful to know the data about inheritance of the more important traits, and to finding out whether high variation is also associated with high heritability estimates and high genetic gain. The easiest and the fastest way to obtain data about the inheritance of quantitative traits will be to conduct a series of crosses amongst phenotypically different individuals, create sufficiently large offspring populations, and then to calculate the regression of offspring on one parent or the regression of offspring on the mid-parent (Falconer 1981; Ollivier 2002). The best way to determine the environmental variance will be to study the variations within clones (i.e. vegetatively propagated individuals of the same age) grown within different environments.

\section{Perspectives for using molecular markers in the breeding process}

Experience with many cultivated species indicates that molecular markers can be used as an efficient tool for the genetic breeding of several plant species (Landjeva et al. 2007; Kalia et al. 2011). They can be very helpful for: assessment of genetic variability and characterisation of germplasm; identification and fingerprint of genotypes; estimation of genetic distances between populations, inbreeds and breeding material; detection of monogenic and qualitative trait loci (QTL); marker-assisted selection; identification of sequences of useful candidate genes, etc. 
Over the last decade Amplified Fragment Length Polymorphism (AFLP) markers have encountered the widest applications regarding the analyses of genetic diversity below the species level in plants, particularly in investigations of population structure and differentiation in both cultivated and natural/rare populations (Blair et al 2010, Del Carpio et al 2011, He and Bjornstad 2012). However the evaluations of the genetic diversity regarding the Christmas rose within naturally occurring Slovenian populations using the AFLP technique have not shown strong differentiation (Šušek 2007). For the evaluation of genetic diversity, it would be helpful to combine AFLP's with other molecular approaches such as simple sequence repeats (SSRs) because they are highly polymorphic, codominantly inherited, abundant and evenly distributed throughout the genome. As mentioned earlier, Christmas roses are probably highly heterozygous. With dominant markers (AFLPs), individuals that are heterozygous for a DNA band at a specific position cannot be distinguished with certainty from individuals that are heterozygous for the same band. With diploid organisms and co-dominant microsatellite markers also known as Simple Sequence Repeats (SSRs), banding patterns may be translated into homozygous or heterozygous genotypes at each locus used for comparison between individuals. More often, however, the binary patterns obtained are used directly during comparisons involving the similarities of individuals (Maguire et al. 2002).

It would also be useful to explore other molecular markers based on the assessment of variability generated by microsatellites sequences such as Single Nucleotide Polymorphisms (SNPs) (Ferguson et al. 2012), Sequence Characterized Amplified Region (SCARs) (Zhang, et al. 2010), and other types of DNA molecular markers such as sequence specific PCR based markers (Expressed Sequence Tags (EST) (Wang et al. 2010).

\section{CONCLUSIONS}

Modern markets require highly competitive cultivation of ornamental plants. On the market, it is possible to find several new, very attractive and highly competitive species. Some of them are wild plants. Diversification of cultivation is becoming very important and involves new species, new varieties and new cultivation technologies.

The Christmas rose is a well known ornamental plant species and is becoming more and more important ornamental on the market. The number of genetically improved varieties of the Christmas rose on the market is limited. The main reasons are: (1) there are only a few breeding companies, (2) genetic breeding is not supported by appropriate genetic research, (3) breeding is based on rather simple approaches and there are long scale breeding programmes (4) international cooperation is limited and (5) genetic resources are improperly evaluated and unavailable for free exchange.

Genetic resources can be considered as one of the key problems, it is difficult for a breeder to obtain appropriate gene sources for specific traits, such as specific flower colours, flower sizes, overlapping sepals, double flowers, plant heights, adaptability to greenhouse environments and resistance to disease and pests. Amongst these, the more important are sources of genes for floral peduncle length, floral diameter, overlapping sepals, double flowers and diversity of floral colours.

Another reason is the sophisticated and time consuming breeding process, which includes evaluation of the parental materials, genetic recombination (crossings) and evaluation of hybrid progenies. From the initial crossing to the flowering of a hybrid progeny, it usually takes 3 years. However, crucial floral characteristics such as floral size and number of flowers per plant could be evaluated at least two years later. The main criteria for selection are: resistance/tolerance to pests and diseases, vigorous growth, large flowers, long peduncles and ability to flower before Christmas when the price reaches its peak.

In the future, breeders will probably have much more reliable data about the diversity and variation within existing germplasm collections and natural habitats. The breeding process, however, will remain sophisticated and time consuming. Its success will depend on many factors: level of the genetic variation, frequency of genotypes expressing desired traits, way of inheritance (simple genetic control, presence of epistasis, interaction between genetic structure and environment etc.), selection method and breeder's experience.

\section{REFERENCES}

1. Atlas RM, Bartha R. Microbial ecology: fundamentals and applications 4th ed. Benjamin Cumming Science, California, 1998.

2. Blair MW, Chaves A, Tofino A, Calderon JF, Palacio JD. Extensive diversity and inter-genepool introgression in a world-wide collection of indeterminate snap bean accessions. Theor. Appl. Genet., 2010;120:1381-91.

3. Del Carpio DP, Basnet RK, De Vos RCH, Maliepaard C, Visser R, Bonnema G. The patterns of population differentiation in a Brassica rapa core collection. Theor. Appl. Genet., 2011;122:1105-18.

4. Dhooghe E, Van Labeke MC. In vitro propagation of Helleborus species. Plant Cell Tiss. Org., 2007;91:175-77.

5. Dunabeitia MK, Hormilla S, Garcia-Plazaola J, Txarterina $\mathrm{K}$, Arteche U, Becerril M. Differential response of three fungal species to environmental factors and their role in the mycorrhization of Pinus radiata D. Don. Mycorrhiza, 2004; 14:11-18.

6. Falconer DS. Introduction to quantitative genetics, 2nd edn. Longman, London and New York, 1981.

7. Ferguson ME, Hearne SJ, Close TJ, Wanamaker S, Moskal WA, Town, CD, de Young J, Marri PR, Rabbi IY, de Villiers EP Identification, validation and high-throughput genotyping of transcribed gene SNPs in cassava. Theor. Appl. Genet., 2012;124:685-95.

8. FloraHolland. Facts and Figures. FloraHolland, Aalsmeer, 2010.

9. FloraHolland. Facts and Figures. FloraHolland, Aalsmeer, 2014.

10. He XY, Bjornstad A. Diversity of North European oat analyzed by SSR, AFLP and DArT markers. Theor. Appl. Genet., 2012;125:57-70. 
11. Hegi G. Illustrierte Flora von Mitteleuropa. Ed. 2. Verlag Paul Parey, Berlin und Hamburg, 1975.

12. Jorgensen RA, Que Q, Napoli CA. Maternallycontrolled ovule abortion results from cosuppression of dihydroflavonol-4-reductase or flavonoid-3,5hydroxylase genes in Petunia hybrida. Funct. Plant Biol., 2002;29:1501-6.

13. Kalia RK, Rai MK, Kalia S, Singh R, Dhawan AK. Microsatellite markers: an overview of the recent progress in plants. Euphytica, 2011;177:309-34.

14. Landjeva S, Korzun V, Boerner A. Molecular markers: actual and potential contributions to wheat genome characterization and breeding. Euphytica, 2007;156:27196. 17. Lemper J. Christrosen mit schnellerer Kultur erfolgreich. Deutscher Gartenbau, 1984;5:186-190.

15. Lemper J. Christrose: alte Pflanze mit sehr hohem Marktwert. Gartnerborse und Gartenwelt, 1985;30:113336. 19. Maguire TL, Peakall R, Saenger P. Comparative analysis of genetic diversity in the mangrove species Avicennia marina (Forsk.) Vierh. (Avicenniaceae) detected by AFLPs and SSRs. Theor. Appl. Genet., 2002;104:388-89.

16. Mathew B. Hellebores. Alpine Garden Society, London, 1989.

17. Meiners J, Winkelmann T. Evaluation of reproductive barriers and realisation of interspecific hybridisations depending on genetic distances between species in the genus Helleborus. Plant Biol., 2012;14:576-85.

18. Nakatsuka T, Nishihara M, Mishiba K, Yamamura S. Heterologous expression of two gentian cytochrome P450 genes can modulate the intensity of flower pigmentation in transgenic tobacco plants. Mol. Breeding, 2006;17: 91-99.

19. Nishihara M, Nakatsuka T. Genetic engineering of flavonoid pigments to modify flower color in floricultural plants. Biotechnol. Lett., 2011;33:433-41.

20. Ollivier L. Éléments de génétique quantitative. $2^{\text {ème }}$ édition revue et augmentée. Paris: INRA et Masson, 2002.

21. Šušek A. Analysis of diversity of Christmas rose (Helleborus niger L.) natural population. Dissertation, University of Burgundy, 2007.

22. Šušek A. Morphological descriptors of Christmas rose (Helleborus niger L.). Agricultura, 2008;6:1-5.

23. Šušek A. Črni teloh-raznolikost v Sloveniji/Helleborus niger-diversity in Slovenia. In: Bavcon J, Eler K, Šušek A (eds) Telohi (Helleborus L.) v Sloveniji/Helleborus (Helleborus L.) in Slovenia, Botanični vrt Univerze/ Botanical garden University, Ljubljana, 2012:145-95.

24. Šušek A, Guillemin JP, Lemoine MC, Gollotte A, Ivančič A, Caneill J, Gianinazzi S. Effect of Rhizosphere Bacteria and Endomycorrhizal Fungi on the Growth of Christmas Rose (Helleborus niger L.) Europ. J. Hort. Sci., 2010;75:85-88.

25. Šušek A, Ivančič A, Lemoine MC, Guillemin JP, Caneill J, Šiško M, Janžekovic F, Praprotnik L. Variability of Christmas rose (Helleborus niger L.) populations and its potential use in genetic breeding. Acta Biol. Cracov. Bot., 2005;47:129-35.

26. Seyring M. In vitro cloning of Helleborus niger. Plant Cell. Rep., 2002;20:895-900.
27. van der Heijden EW, Vries FW, Kuyper TW. Mycorrhizal associations of Salix repens L. communities in succession of dune ecosystems. I. Above-ground and below-ground views of ectomycorrhizal fungi in relation to soil chemistry. Can. J. Bot., 1999;77:1821-32.

28. Vessey KJ. Plant growth promoting rhizobacteria as biofertilizers. Plant Soil, 2003;255:571-86.

29. Zhang WW, He HL, Guan Y, Du H, Yuan LH, Li Z, Yao DQ, Pan JS, Cai R. Identification and mapping of molecular markers linked to the tuberculate fruit gene in the cucumber (Cucumis sativus L.). Theor. Appl. Genet., 2010;120:645-54.

30. Wang MJ, Zhang Y, Lin ZS, Ye XG, Yuan YP, Ma W, Xin ZY. Development of EST-PCR markers for Thinopyrum intermedium chromosome $2 \mathrm{Ai} \# 2$ and their application in characterization of novel wheat-grass recombinants. Theor. Appl. Genet., 2010;121:1369-80. 


\section{Pregled in možnosti žlahtnjenja črnega teloha (Helleborus niger L.)}

\section{IZVLEČEK}

Črni teloh postaja na trgu okrasnih rastlin zelo pomembna rastlinska vrsta, ki pa je relativno nova vintenzivni proizvodnji. Število novih požlahtnjenih sort je na trgu sorazmerno nizko. Veliko starih sort ni več na voljo zaradi počasnega in ekonomsko nerentabilnega vegetativnega razmnoževanje. V prihodnosti bo potrebno zagotoviti nove atraktivne sorte, ki bodo morale izpolnjevati posebne zahteve trga in proizvajalcev, kakor tudi stroge okoljske omejitve. Uspeh žlahtnjenja novih sort je odvisen predvsem od genetske variabilnosti razpoložljivih materialov v genskih kolekcijah in naravnih populacijah ter izbrane metode dela. Obstaja sedem različnih možnosti za oblikovanje novih sortnih materialov: uporaba naravne variabilnosti v povezavi z uporabo semen, populacijsko žlahtnjenje (ki temelji na rekurentni selekciji), neposredna odbira najboljših osebkov iz potomstev specifičnih genskih kombinacij (križanj ali samooploditev), ustvarjanje homozigotnih linij in oblikovanje hibridov, medvrstna hibridizacija, oblikovanje mutacij in genski inženiring. V procesu žlahtnjenja so lahko zelo koristni tudi molekulski markerji, ki se lahko prav tako uporabljajo za proučevanje genetske sorodnosti med populacijami, ekotipi, sortami in hibridi.

Ključne besede: črni teloh, Helleborus niger, sorte, možnosti žlahtnjenja 